\title{
Does Foreign Banks Entry Influence Domestic Banks' Efficiency? Evidence from Ghana
}

\author{
Eric Osei-Assibey \\ Department of Economics \\ University of Ghana \\ Legon, Accra
}

\section{William Bekoe}

Department of Economics

University of Ghana

Legon, Accra

\section{Michael Armah}

Department of Economics

University of Ghana

Legon, Accra

\section{Correspondence:}

Email: eoassibey@ug.edu.gh https://dx.doi.org/10.4314/ajmr. v27i1.4

\begin{abstract}
The study investigates the effect of foreign bank entry on the efficiency of domestic banks in Ghana. The study applies the Stochastic Frontier Analysis (SFA) technique and the system Generalized Method of Moments (GMM) estimator on bank specific level data, spanning the period 2000 to 2015. The results show that foreign banks with an average profit efficiency of $74.7 \%$ are more profit efficient than domestic banks with a score of $71 \%$ which conforms to the global advantage hypothesis. This suggests that foreign banks are able to maximize revenue through the generation of interest income on loans and investments better than domestic banks due to the foreign banks' comparative advantage in terms of international expertise. Further, the system GMM results indicate that the entry of foreign banks has contributed to the profit efficiency of domestic banks in Ghana. This positive spillover effect of foreign banks is manifested in their transfer of international expertise, technological knowledge, quality banking services and competitive pressure to domestic banks. In addition, bank size and liquidity are essential determinants of the profit efficiency of domestic banks in Ghana. The findings of the study imply that bank regulators in developing countries should push for reforms that eliminate implicit and explicit barriers that may hinder the entry of foreign or new banks.
\end{abstract}

\section{Introduction}

Banking has increasingly become more globalized, driven by deregulation, improvement in communications and technology, and more importantly economic integration (Berger et al., 2000). Over the last few 
decades, the entry of foreign banks in developing countries has in-creased sharply, although there is variation in the mode of entry. Foreign banks in most developing countries control over eighty (80) percent of the shares of the banking industry (Kiyota, 2011). In regions like Africa, foreign bank entry has taken an increasing turn due to the reduction of trade barriers in financial services. The trend is the same in Ghana, where, the influx of foreign banks has increased steadily over the years with foreign banks owning more than 60 percent of equity capital (Adjei and Chakravarty, 2012).

It is now well documented that the influx of new banks into a domestic banking industry does not only strengthen competition among banks, but also promotes efficiency by way of technological transfer and adoption of global best practices. It also allows banking techniques such as good corporate governance and innovations to spillover to domestic banks (Detragiache et al., 2008). In other words, they transfer to domestic banks the skills and technology that enhance risk management and internal controls. It has been argued that the entry of foreign bank brings about competition to domestic banks, which is noted for playing a role in quality and access to financial services as well as efficiency in their operations.

However, what is not certain in the extant literature is whether foreign banks entry influences domestic banks efficiency. Clarke et al.,(2005) argue that while the entry of large foreign banks promotes small enterprises' access to finance, if these foreign banks are too many to the extent that they dominate the industry in terms of asset and branches, it might lead to unfair competition against the domestic banks and in some cases cause serious impairments that can eventually knock them out of the market. This might be so because foreign banks have the capacity and resources to investigate and get information (both soft and hard) about borrowers and businesses they can embark on anticompetitive schemes by "cherry picking" borrowers, which will worsen the remaining credit pool for small domestic banks (Detragiache et al., 2008). Moreover, most of the profits gained by foreign banks are channeled into major investible projects in their native countries. This can have an overall negative effect on small businesses by mitigating the positive effect of foreign bank entry experience.

Since the beginning of the financial sector reforms and liberalization program in 1988 (which became known as FINSAP) as part of the World Bank-IMF sponsored market based structural adjustment program in 1983, the entry of foreign banks into Ghana's domestic market has increased tremendously. As at the start of the study period in 2000, there were 16 banks of which 6 were foreign owned. At the end of 2015, 17 foreign banks out of 29 banks dominate the banking industry in Ghana. Increasing foreign ownership within the banking industry poses an interesting issue concerning the role of foreign banks in developing countries. Although, a growing number of studies (Saka 2012; Adjei and Chakravarty 2012; and Alhassan and Ohene-Asare 2016) have focused on the technical efficiency of banks in developing countries, the literature on the effect that the entry of foreign banks has on the domestic indigenous banks is limited. 
Moreover, despite the influx of foreign banks into the country's banking space that has, in no doubt, increased competition and deepened financial intermediation, and the expected positive spillover effect on domestic banks' efficiency, the recent banking crisis in Ghana makes revisiting this issue even more critical for the future stability of the banking sector. It is interesting to note that all the seven banks and several other nonbank financial institutions that got their licenses revoked between 2017 and 2019 by the Bank of Ghana were domestic and largely homegrown banks and institutions. While the central bank and experts have attributed the collapse of these banks to the absence of good corporate governance practices as the key factor leading to their collapse, it will be important to gauge whether domestic banks have benefited in anyway (particularly in efficiency gains) from the influx of foreign banks which normally comes with international best practices in good corporate governance and management. Or whether their presence is inimical to the stability and growth prospects of domestic banks.

The key question therefore is, what is the effect of the influx of foreign banks on domestic banks' performance in terms of their efficiency? This paper first estimates and compares the efficiency levels of foreign banks with domestic banks and second, investigates whether foreign bank entry contributes to the efficiency of the banking industry in Ghana. The paper adds to the existing literature by examining the profit efficiency of banks in Ghana using the Stochastic Frontier Analysis (SFA) technique as opposed to the cost efficiency and Data Envelopment
Analysis (DEA) approach which dominate the banking efficiency studies in Ghana. Empirical works using the nonparametric DEA methods typically focus on technology rather than economic optimization. They are therefore not suitable for comparing firms specializing in different inputs or outputs (Ikhide, 2000). The two advantages that the SFA has over the non-parametric DEA is that it separates random errors from the production inefficiency taking into consideration the prevalence of exogenous shock and also less sensitive to outliers. The inefficiency and random error terms are separated by making explicit assumptions about their distributions.

The rest of the study is organized as follows: Section 2 presents some stylized facts about the Ghanaian banking industry. Section 3 provides the theoretical and empirical literature on banking efficiency. Section 4 outlines the empirical model, the estimation techniques and sources of data. Section 5 presents the empirical results and Section 6 concludes.

\section{Overview of the Ghanaian Banking Industry}

Prior to the financial sector reforms in the late 1980 's, there were only 11 banks of which state-owned banks dominated the banking system. Most of the banks set up were wholly or majority owned by the public sector, while government acquired minority shares of about 40 percent in foreign banks. Out of eleven (11) banks, which existed prior to the reforms, only two (2) were foreign-owned banks and the remaining nine (9) banks were stateowned banks. Figure 1 depicts the trend of the ownership structure of banks in Ghana during the period 2000 to 2015. 


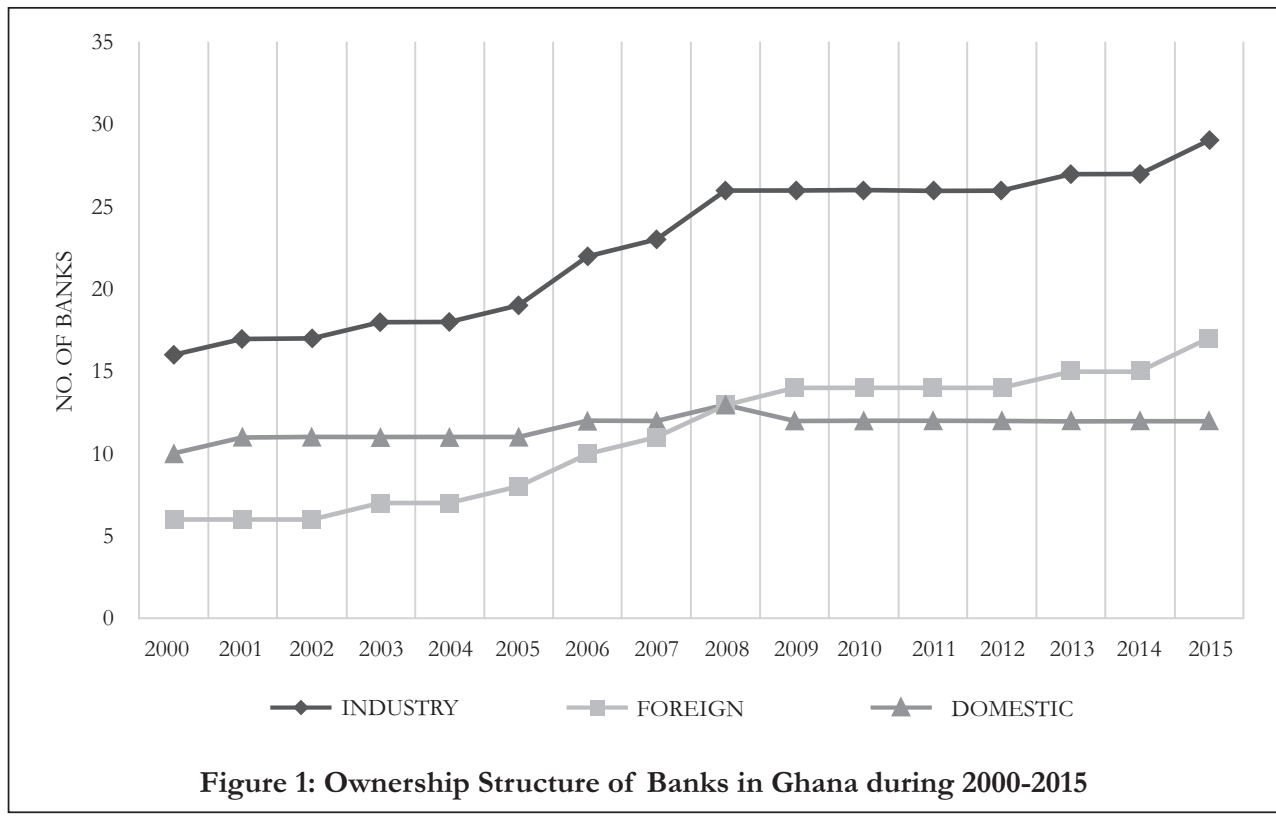

Source: Author's computation using data from the Ghana Banking Survey

As indicated in Figure 1, the number of foreign domestic banks has been increasing over the years. The influx of foreign banks has more than doubled from six (6) at the beginning of the study period in 2000 to seventeen (17) in 2015 due to the ongoing financial sector reforms that includes the liberalization of the financial sector. During the 2000 to 2015 period, there have been lots of mergers and acquisitions, liquidation of banks as well as privatization of some state-owned banks in Ghana due to increasing adjustments in regulatory, capital or minimum capital requirement (Osei-Assibey and Asenso, 2015). The banking sector is relatively small, consisting of 29 universal banks as at the end of 2015 of which seventeen (17) foreign banks and twelve (12) domestic banks. According to the IMF Staff Report (2013), the banking industry in Ghana is highly concentrated, with the top five biggest banks accounting for more than fifty (50) percent share of the market in terms of total assets, which is relatively moderate compared to other countries in the region.

The banking industry in Ghana has undergone some challenges of which public domestic banks have been the most affected. The industry has witnessed high risk of non-performing loans due to ineffective monitoring and screening as well as banks inability to deal with economic hardships in the country. The efficiency of public domestic banks and even some foreign banks have declined, hence the Bank of Ghana (BOG) has further increased the minimum capital requirement of banks in Ghana to about GHф120 million which was implemented for all banks at the end of 2012. 
The BOG also increased the monetary policy rate to 21 percent in November 2014 from the 16 percent rate in December in 2013 and raised it further 22 percent in 2015. The increases in the monetary policy rate were to assist in controlling the effect of inflation and depreciation of the local currency (Ghana Cedi). The average lending rate increased from 25.6 percent in 2013 to 28.9 percent in 2014 due to an increase in the average base rate from 21.5 percent in 2013 to 25.7 percent in 2014. The increase in the average lending rates resulted in an increase in the total industry interest income on loans and advances to about 64 percent in 2014 (Ghana Banking Survey, 2015).

\section{Literature Review \\ The Efficiency Concept}

In general, efficiency measures a firm's ability in minimizing costs, maximizing revenues, or maximizing profits, contingent on existing technology. The theoretical framework of efficiency is premised on the studies of Koopmans (1951) and Debreu (1951) and it is related to cost and the production function introduced by Shephard (1953 and 1970). His production function considered multiple outputs which are different from classical production theories of a single output. Efficiency is defined as the ratio of weighted outputs relative to weighted inputs. According to Berger and Humphrey (1997), efficiency measurement in banking industry refers to banks' ability to generate outputs (render an optimal combination of financial services) with a given set of resources (inputs). Efficiency measurement ranges between zero, corresponding to the least measure and one, indicating the optimum.
From the extant literature, there are two main concepts of efficiency applied in banking efficiency, namely; cost efficiency and profit efficiency. Cost and profit efficiency definitions correspond to the essential goals of economics. Thus, minimization of cost and maximization of profit. Both cost and profit efficiency are important because banks seek cost and profit optimization by minimizing cost as well as maximizing profit.

\section{Profit Efficiency}

Profit efficiency refers to the ability of a bank in maximizing its profit with a specified level of inputs and prices of outputs. It relates to the profit function which captures the economic goals of firms, by considering both costs and revenues. Thus, it offers more useful information for managers in evaluating efficiency. Based on the market conditions, profit efficiency can be estimated in two forms, namely, standard profit efficiency and alternative profit efficiency. Standard profit efficiency is premised on the assumption of a perfectly competitive market in which firms have no control in influencing prices in the input and output markets. Alternative profit efficiency assumes the existence of imperfect competition within the input and output markets. Thus, it is premised on the assumption of firms having market power in price settings. Banking firms take the prices of inputs and output quantities as given. Hence alternative profit efficiency is estimated using prices of inputs and output quantities instead of output prices. This paper adopts profit efficiency because it constitutes a better measurement of efficiency than cost efficiency, since it considers both revenue and costs and thus provides a complementary information in 
addition to cost efficiency. Hence it provides a useful information for managers in evaluating efficiency (Maudos et al., 2000). Additionally, profit efficiency captures the revenue effect reflecting on the differences of management's decisions or investments that are neglected in cost efficiency which ignores variation in revenue across banks. According to Berger and Mester (2003), the "use of profit approach may help take into account unmeasured changes in the quality of banking services by including higher revenues paid for the improved quality, and may help to capture the profit maximization goal by including both costs and revenues".

\section{Empirical Review}

Empirical studies on banking efficiency have sought to examine the effect of foreign bank entry on the efficiency of banks. Foreign bank entry refers to the situation whereby foreign banks establish operations in another country by setting up a subsidiary or a branch.

The literature on bank ownership and efficiency is very broad and comprehensive. Research on these studies across the globe suggests that in developing countries, foreign banks operate efficiently compared with domestic banks. This may be attributed to the theory of global advantage hypothesis postulated by Berger et al., (2000) which asserts that foreign banks outperform domestic banks due to advanced technologies and superior managerial skills. In developed countries, foreign banks are less efficient compared with domestic banks as stated by the home-field hypothesis in the form of competitive advantages for domestic banks stemming from subculture, lan- guage differences, and absence of organizational diseconomies. In summary, in developing countries, foreign banks are more efficient compared with domestic banks whereas, in developed countries, domestic banks operate efficiently relative to foreign banks (Claessens et al., 2001). The extant studies are ambivalent concerning banking efficiency under different ownership. The following are some studies whose main focus were based on cost and / or profit efficiency, comparative analysis of the efficiency of domestic and foreign banks, the impact of foreign bank entry on operations of domestic banks around the globe, Africa and in Ghana.

Claessens et al., (2001) suggest that in developing countries, foreign banks are more profitable compared with domestic banks while domestic banks had a lower profit than domestic banks in developed countries. The study examined the effect of foreign bank entry on domestic banking markets using a sample of 80 countries between 1988 and 1995 . Further, the results suggest that the influx of foreign banks leads to a decrease in the profit margins of domestic banks. Similarly, Liutho et al., (2006) found evidence which suggests that the influx of foreign banks leads to a reduction in profitability and revenue for domestic banks. Using a dynamic panel estimation for a sample of 319 banks from ten (10) Central and Eastern European Countries (CEEC) over the 1995-2001 period, the study analyzed the short-term effect of the influx of foreign banks on performance within the banking industry. The findings of the study further revealed that the influx of foreign banks increases the overhead cost of domestic banks suggesting that, in the short run the entry of 
foreign banks raises competition within the domestic banking industry.

Sturm and Williams (2004) in their study "Foreign bank entry, deregulation and bank efficiency" analyzed banking efficiency in Australia covering the period 1998-2001. Using both DEA and SFA approaches, they analyzed the technical and scale efficiencies of banks in Australia during the pre-deregulation era and postderegulation period. They found evidence that foreign banks have a higher input efficiency level compared with domestic banks primarily due to foreign banks' superior scale efficiency during the postderegulation period.

Karas et al., (2010) measured the efficiency of banks in Russia over two points in time (2002 and 2006). The study employed the Stochastic Frontier Analysis in estimating the efficiency of domestic and foreign banks in Russia. The findings indicated that foreign banks and state-owned banks are more efficient than private domestic banks. The difference in efficiency levels between state-owned banks and private domestic banks has not reduced since the introduction of insurance deposits. The study concluded that the influx of foreign banks contributes more to the efficiency of the banking industry in Russia, which is consistent with the study by Liao (2010). Rouissi and Bouzgarrou (2012) evaluated the efficiency of domestic and foreign banks in France from 2000 to 2007. The study used the Stochastic Frontier Analysis in examining factors that determine cost efficiency for a panel of 40 foreign and 62 domestic banks. The findings of the study suggest that foreign banks operate more efficiently compared with domestic banks, which contradict previous empirical studies such as Claessens et al., (2001) and Lensink et al., (2008) which concluded that in developed countries, domestic banks are more efficient.

Pertaining to studies in Africa, Kirkpatrick et al., (2008) analyzed the cost and profit efficiency for a panel of 89 banks in 9 countries in Sub-Saharan Africa (SSA). The results revealed that profit inefficiency is relatively higher compared to cost inefficiency. The findings of the study further indicated that the influx of foreign banks leads to a reduction in inefficiency implying that foreign banks' entry enhances the performance of domestic banks in SSA. Kiyota (2011) sought to compare the efficiency of domestic and foreign banks for a sample of 29 countries in SSA covering the period 2000 to 2007. Utilizing the parametric approach (SFA), the study analyzed the cost and profit efficiency of banks under different ownership. The second stage analysis employed Tobit regression to investigate factors that affect the efficiency of banks in SSA. The results reveal that foreign banks are more efficient compared with domestic banks and also the influx of foreign banks enhances the efficiency of domestic banks.

Regarding studies in Ghana, Saka et al., (2012), analyzed the technical efficiency of Ghanaian banks using the DEA technique for a sample of 25 banks spanning the period of 2000-2008. The study sought to evaluate foreign bank entry on the efficiency of domestic banks. Using the Tobit regression in the second stage, independent variables were regressed on efficiency estimates. The findings suggested that the influx of foreign banks coupled with a less concentrated industry 
contributes to the efficiency of domestic banks. The results of the study revealed that the mean efficiency estimates of domestic banks were higher than the average efficiency score for domestic banks, which may be due to high start-up costs that foreign banks face when entering the host country.

On the contrary, Bokpin (2013), examined the "effect of ownership structure and corporate governance on bank efficiency" within the banking industry in Ghana during 1999-2007 period. Employing the SFA method, efficiency measures were computed using both translog cost and profit functions. He found evidence that foreign banks have cost advantages over domestic banks. On the other hand, domestic banks are more profit efficient than foreign banks in Ghana. The variation in the findings of Saka et al., (2012) and Bokpin (2013) may be attributed to different efficiency measures and estimation techniques employed.

\section{Methodology}

\section{Methods for Estimating Efficiency}

Most of the studies in the literature have focused on conventional accounting ratios (simple ratio-based) including return on assets, return on equity and net interest margin, while others have employed a number of alternative frontier efficiency measurement methods. The frontier methods, premised on economic theory, evaluate the performance of banks in a multi-dimensional framework by considering multiple inputs and outputs. Additionally, frontier techniques give reliable and consistent performance of decision-making units compared to the conventional ratio analysis. Hence the frontier estimation is deemed superior to the conventional ratio analysis.

There are two major approaches that are mostly used in measuring efficiency frontier. These are the parametric method and non-parametric method. The parametric approach specifies a precise functional form for the frontier and estimates parameters using sample data for inputs and output. Estimation of efficiency using a parametric technique is premised on economic optimization, given the basic assumption of a stochastic optimal frontier. The most applied parametric methods in bank efficiency include the Stochastic Frontier Analysis (SFA), Distribution-Free Approach (DFA) and the Thick Frontier Approach (TFA). The non-parametric approach, on the other hand, does not require a specific functional form in estimating the frontier. It captures the measurement of technological efficiency, based on technology and not economic optimization. Examples of the non-parametric method used in banking efficiency include Data Envelopment Analysis (DEA) and Free Disposal Hull (FDH). This paper adopts the SFA because it is the most widely used parametric technique. An advantage of the parametric technique is that it considers the use of hypothesis testing in relation to the goodness of fit of the model. Its demerit, however, lies in the fact that it requires an explicit functional form which may be restricted in most cases.

\section{The Stochastic Frontier Analysis (SFA)}

The SFA originated from the studies of Aigner and Chu (1968), Battese and Corra (1977) and Meeusen and Broeck (1977). The SFA specifies a functional form of the output variable (profit efficiency), 
makes provision for the random error term as well as permitting the making of inferences. The transcendental logarithmic (translog) functional form is employed in estimating profit frontier functions because the translog specification is very simple, flexible and most commonly used. Some of the notable studies that have made use of SFA include: Bonin et al., (2005), Karas et al., (2010), Kiyota (2011) and Bokpin (2013).

\section{Estimation of Profit Efficiency using SFA}

Profit efficiency refers to the ability of a bank in maximizing its profit with a specified level of inputs and prices of outputs. It relates to the profit function which captures the economic goals of firms, by considering both costs and revenues.

The study adopts alternative profit efficiency measure in estimating profit efficiency. As opined by Berger and Mester (1997), alternative profit efficiency is very useful and realistic when the assumptions of perfectly competitive markets do not hold as in the case of Ghana. Additionally, banks exhibit higher variability of output quantities compared to prices of outputs and thus can better explain the variation in the dependent variable (Tabak et al., 2011).

The SFA in estimating profit efficiency following a translog specification is expressed as:

$$
\begin{aligned}
& \operatorname{In}(\pi+\Phi+1)=\alpha_{0}+\sum_{i} \alpha_{i} \operatorname{In} W_{i}+\sum_{i} \beta_{i} \operatorname{In} Y_{i}+1 / 2 \sum_{i} \Sigma_{j} a_{i j} \operatorname{In} W_{i} \operatorname{In} W_{j}+ \\
& 1 / 2 \sum_{i} \sum_{j} \beta_{i j} \operatorname{In} Y_{i} Y_{j}+1 / 2 \sum_{i} \Sigma_{j} \gamma_{j} \mathrm{j} \operatorname{In} W_{i} Y_{j}+\sum_{i} \delta_{i} \operatorname{In} Z_{i}+1 / 2 \sum_{i} \sum_{j} \delta_{i j} \operatorname{In} Z_{i} Z_{j}+ \\
& 1 / 2 \sum_{i} \Sigma_{j} \theta_{i j} \operatorname{In} Z_{i} Y_{j}+1 / 2 \sum_{i} \sum_{j} \rho_{i j} \operatorname{In} Z_{i} W_{j}+V_{i t}-U_{i t},
\end{aligned}
$$

where,

$\pi$ denotes profit before tax;

$\Phi$ is defined as the absolute minimum value of profit $(\pi)$ for banks used to eliminate negative profit;

$W$ denotes prices of inputs;

$Y$ denotes quantities of outputs;
Z denote a set of control variable; and $\alpha, \beta, \gamma, \delta, \theta$, and $\rho$ are unknown parameters to be estimated. Profit efficiency estimates lies between zero, which is the lowest efficiency measure and one denoting the most efficient measure. Any deviation from one indicates banks' inefficiency.

Table 1: Summary of variables employed in profit functions

\begin{tabular}{ll}
\hline Symbol & Definition \\
\hline$\pi$ & Profit before tax \\
\hline $\mathrm{Y}_{1}$ & Outputs \\
$\mathrm{Y}_{2}$ & Loans and Advances \\
\hline
\end{tabular}


Table 1 (continued)

\begin{tabular}{ll}
\hline Symbol & Definition \\
& Input Prices \\
$\mathrm{W}_{1}$ & Price of Deposits $=$ (Interest Expense/Deposits) \\
$\mathrm{W}_{2}$ & Personnel/Labour Price = (Personnel Expenses $/$ Total assets) \\
$\mathrm{W}_{3}$ & Depreciable assets = (Other operating expenses/Total assets) \\
\hline & Control variables \\
$\mathrm{Z}_{1}$ & Equity/Total assets \\
$\mathrm{Z}_{2}$ & Total assets (proxy for size) \\
& \\
\hline
\end{tabular}

Source: Author's construct

\section{Definition of Inputs and Outputs Variables}

The paper adopts the intermediation approach for evaluating bank efficiency as pioneered by by Sealey and Lindley (1977) which considers banks as financial intermediaries channeling funds from surplus spending units (savers) to deficit spending units (borrowers). The intermediation method as indicated by Berger and Humphrey (1997) is most appropriate for evaluating banking efficiency because managers of banks take into account the reduction of total cost as well as noninterest expenses. The selection of inputs and outputs is in line with studies such as Kiyota (2011), and Adjei-Frimpong et al., (2014). All inputs, outputs, and control variables are measured in Ghana cedis (GHS). Table 2 provides a summary of variables and their definition used in analyzing profit efficiency.

\section{Model Specification for Foreign Bank entry on Efficiency of Domestic Banks}

The second stage analysis of this study is to analyze the effect of foreign bank entry on the efficiency of domestic banks based on the profit estimates. The study adopts the model by Claessens et al., (2001) to capture the influence of foreign bank entry on domestic banks' efficiency. The model employed in this study differs slightly from the former study in that, this study focuses on profit efficiency as the dependent variable, whilst the former applies profit before tax as the dependent variable. In this study, domestic banks are banks that are legally incorporated in Ghana with at least sixty (60) percent of capital equity shares held by Ghanaians. In contrast, foreign banks are banks with at least sixty (60) percent of capital equity shares held by foreigners (Banking Act, 2004). Following Clasessens et al., (2001), the model is specified as:

$$
\begin{aligned}
& E F F_{i t}=\beta_{0}+\beta_{1} E F F_{i t-1}+\beta_{2} \Delta \mathrm{FS}_{i t}+\beta_{3} S I Z E_{i t}+\beta_{4} L I Q D_{i t}+\beta_{5} C A P_{i t}+ \\
& \beta_{6} E X P_{i t}+\beta_{7} H H I_{i t}+\beta_{8} I N F L_{i t}+\beta_{9} G D P_{i t}+\eta_{i t}+\varepsilon_{i t}
\end{aligned}
$$


where,

$\Delta$ is the difference operator which helps in assessing the foreign bank entry on the efficiency of each domestic bank;

$E F F$ is the profit efficiency for domestic banks;

FS denotes foreign banks' share of the markets;

SIZE denotes banks size;

$L I Q D$ denotes liquidity;

$C A P$ denotes capitalization;

EXP denotes experience of a bank;

HHI denotes Herfindahl-Hirschman Index;

\section{INFL denotes inflation rate; and}

$G D P$ denotes growth in Gross Domestic Product.

Further, $\beta$ 's are parameters to be estimated, $\eta_{i t}$ denotes bank specific effect and $\varepsilon_{i t}$ denotes the error term; $i$ denotes individual bank at time $t$.

\section{Estimation Technique}

This paper employs panel regression analysis with STATA 13 as the analytical software in estimating the influence of foreign banks' entry on domestic bank efficiency. A dynamic panel data model is specified by including one-year lagged efficiency among the explanatory variables to capture the dynamic nature of profit efficiency of banks. AdjeiFrimpong et al., (2014), asserts that previous level of efficiency indicates accumulation of knowledge and technological endowment that may assist banks to produce higher outputs with their inputs.

The system General Method of Moments (GMM) estimation technique is employed in estimating the dynamic panel model. The GMM technique uses lags of endogenous variables as instruments; in which the endogenous variables are predetermined hence are not correlated with the error term. This paper utilizes the system GMM technique as opposed to the difference GMM technique. The system GMM technique as designed by Arellano and Bover (1995) and Blundell and Bond (1998) seeks to address issues of the weak instrument associated with the difference GMM technique using level equation and differenced equation. The efficiency of the equation under estimation is improved if moment conditions of its level form and the differenced forms are combined (Roodman, 2009). Lagged differences are used as instruments for endogenous variables in the level equations since these values become the suitable instruments in view of additional moment conditions. The system GMM is considered the most appropriate panel regression estimation technique due to its ability to resolve the endogeneity problem by the use of lagged values of explanatory variables as instruments and also it allows the use of level and lagged values of the variables used in the equation under estimation. Table 2 provides a summary description of variables used in the GMM regression.

\section{Data Sources and Scope of the study}

The study uses a panel model with data extracted from the end of year balance sheet statements and the annual income statements of banks. In addition, data on macroeconomic variables such as gross domestic product and inflation were 
culled from the World Development Indicators (WDI, 2016). Data on the annual financial reports for the selected banks is acquired from the Ghana Association of Bankers. The sample for this study is drawn from twenty seven (27) universal banks in Ghana (twelve domestic banks and fifteen foreign banks) for the period 2000 to 2015 .

Table 2: Summary of variables employed in profit functions

\begin{tabular}{|c|c|c|c|c|}
\hline Symbol & Variable & Definition & Measurement & $\begin{array}{l}\text { Prior } \\
\text { Expectation }\end{array}$ \\
\hline \multicolumn{5}{|c|}{ DEPENDENT VARIABLE } \\
\hline EFF & $\mathrm{EFF}$ & Profit efficiency & $\begin{array}{l}\text { Profit efficiency derived from SFA } \\
\text { estimations. }\end{array}$ & \\
\hline \multicolumn{5}{|c|}{ BANK SPECIFIC } \\
\hline$\beta_{1}$ & FS & Foreign Share & $\begin{array}{l}\text { Ratio of foreign bank assets to total } \\
\text { bank assets }\end{array}$ & + \\
\hline$\beta_{2}$ & CAP & Capitalization ratio & Equity over total assets & $+/-$ \\
\hline$\beta_{3}$ & SIZE & Bank size & The natural log of total assets & + \\
\hline$\beta_{4}$ & LIQD & Liquidity & Total loans to total deposits & $+/-$ \\
\hline$\beta_{5}$ & EXP & Age & Year of incorporation & + \\
\hline \multicolumn{5}{|c|}{ INDUSTRY } \\
\hline$\beta_{6}$ & HHI & $\begin{array}{l}\text { Herfindahl- } \\
\text { Hirschman Index }\end{array}$ & Sum of squares of market shares (MS) & + \\
\hline \multicolumn{5}{|c|}{ MACRO } \\
\hline$\beta_{7}$ & INFL & Inflation & Year-to-year change in the CPI & $+/-$ \\
\hline$\beta_{8}$ & GDP & $\begin{array}{l}\text { Gross Domestic } \\
\text { Product }\end{array}$ & $\begin{array}{l}\text { The growth in GDP to measure the } \\
\text { size of the economy }\end{array}$ & + \\
\hline
\end{tabular}

Source: Author's construct

Table 3: Basic results of profit efficiency for the industry

\begin{tabular}{ll}
\hline Mean & $\mathbf{0 . 7 1}$ \\
\hline Standard deviation & 0.17 \\
Minimum & 0.00000000658 \\
Maximum & 0.958 \\
$\mathrm{~N}$ & 278 \\
\hline & \\
Log likelihood function & -170.0245 \\
Wald chi2(25)(Prob > chi2) & $13338.480 .000)$ \\
Variances: $\quad$ sigma_u & 4.614 \\
\multicolumn{2}{c}{ sigma_v } \\
\hline
\end{tabular}

Source: Author's construct 


\section{Empirical Results}

The industry results indicate a mean efficiency score of $71 \%$ for banks in Ghana. This suggests that Ghanaian banks are 71 percent efficient in generating optimal outputs. Thus, banks in Ghana incur a huge loss of $29 \%$ in employing the same level of inputs to produce outputs. Table 3 presents the basic results of profit efficiency for the banking industry in Ghana.

Figure 2 and Table 4 present a trend analysis of profit efficiency estimates for domestic and foreign banks during the period 2000-2013. The results show that foreign banks with an average profit efficiency of $73.7 \%$ are more profit efficient than domestic banks with a score of $69.2 \%$ which conforms to the global ad- vantage hypothesis. This suggests that foreign banks are able to maximize revenue through the generation of interest income on loans and investments better than domestic banks due to the foreign banks' comparative advantage in terms of international expertise. The results of this study are in line with other studies such as Bonin et al., (2005) for eleven developing nations and Kiyota (2011) for 29 countries in SSA. Similarly, the profit efficiency of domestic and foreign banks exhibit an upward and downward trend during the 2001-2008 period. The period 2011-2013 shows a consistent upward trend for foreign banks indicating an improvement in profit efficiency over time, whereas the same period indicates an undulating trend for domestic banks.

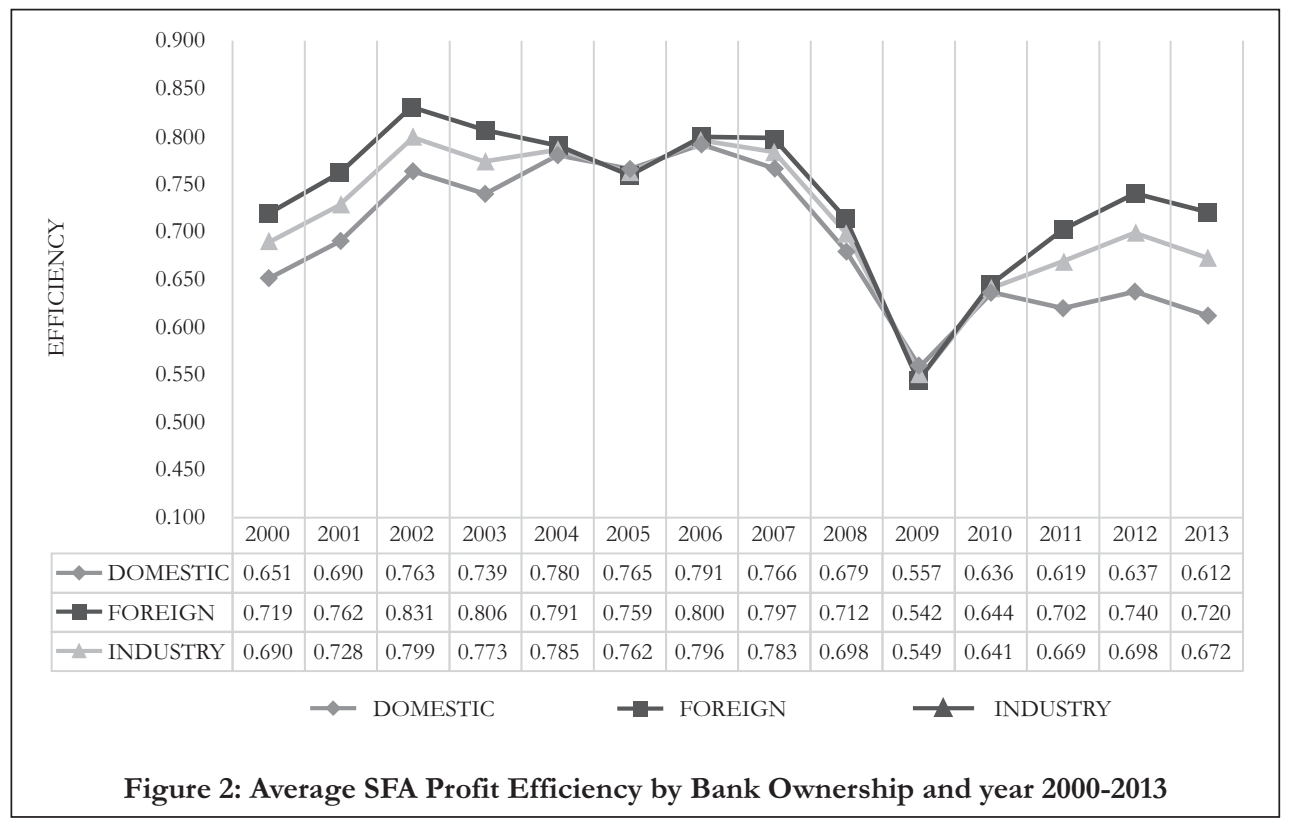

Note: Average values for the period 2000-2013: domestic banks (0.692) and foreign banks (0.737). 
Table 4: Profit Efficiency Estimates of Banks in Ghana

\begin{tabular}{lll}
\hline \multirow{2}{*}{ Year } & Domestic Banks & Foreign Banks \\
\cline { 2 - 3 } & Mean & Mean \\
\hline 2000 & 0.651 & 0.719 \\
2001 & 0.690 & 0.762 \\
2002 & 0.763 & 0.831 \\
2003 & 0.739 & 0.806 \\
2004 & 0.780 & 0.791 \\
2005 & 0.765 & 0.759 \\
2006 & 0.791 & 0.800 \\
2007 & 0.766 & 0.797 \\
2008 & 0.679 & 0.712 \\
2009 & 0.557 & 0.542 \\
2010 & 0.636 & 0.644 \\
2011 & 0.619 & 0.702 \\
2012 & 0.637 & 0.740 \\
2013 & 0.612 & 0.720 \\
$\mathbf{2 0 0 0 - 2 0 1 3}$ & $\mathbf{0 . 6 9 2}$ & $\mathbf{0 . 7 3 7}$ \\
\hline
\end{tabular}

Source: Author's construct

\section{Effect of Foreign bank entry on efficiency of Domestic banks}

The second stage analysis of this paper follows the model suggested by Claessens et al,. (2001). This objective under this section is to examine the effect of foreign bank entry on the efficiency of domestic banks. The share of foreign banks' assets to total assets in the industry (Foreign share) is employed as a proxy to capture the effect of foreign bank entry. Foreign share, bank-specific variables, industry variables and macroeconomic variables are regressed on the profit efficiency estimates of domestic banks. Table 5 provides the descriptive statistics of variables used in the regression analysis.

Table 5: Summary Statistics of variables

\begin{tabular}{llllll}
\hline Variable & Mean & Std. Dev. & Min & Max & N \\
\hline EFF & 0.69 & 0.16 & $6.58 \mathrm{E}-09$ & 0.90 & 123 \\
FS & 0.55 & 0.02 & 0.52 & 0.61 & 123 \\
CAP & 0.12 & 0.06 & 0.00 & 0.39 & 123 \\
SIZE & 19.40 & 1.39 & 14.81 & 21.94 & 123 \\
LIQD & 0.75 & 0.30 & 0.05 & 1.98 & 123 \\
EXP & 27.33 & 16.12 & 2 & 60 & 123 \\
HHI & 0.01 & 0.01 & 0.00 & 0.07 & 123 \\
INFL & 15.30 & 6.75 & 8.73 & 32.91 & 123 \\
GDPG & 6.85 & 2.77 & 3.70 & 14.05 & 123 \\
\hline
\end{tabular}

Source: Author's construct

Table 6 presents the empirical results of the effect of foreign bank entry on the efficiency of domestic banks. The estimated model using the GMM estimator indicates that the Wald test is highly significant at the $1 \%$ level. This 
suggests that overall the estimated model is good. Based on the analysis of the residuals, the White/Huber robust standard error is applied to address the presence of heteroscedasticity. As indicated earlier, the system GMM estimator is chosen over the static model (Random Effect Model and Fixed Effects Model) because some of the explanatory variables are endogenous. Hence the analysis is based on the GMM estimation in equation (3).

In relation to the GMM, the p-value of Arellano-Bond test statistics for the second order serial correlation AR (2) in the residuals fails to reject the null hypothesis of no presence of second-order autocorrelation within the error term since the $\mathrm{p}$ value of $A R(2)$ is 0.535 indicating that it is insignificant. Thus, there is no second order serial correlation within the error term. Accordingly, the Hansen test of over-identification reports that the instruments used in the system GMM estimation are valid.

The results in model (3) in Table 6 indicate that foreign share (FS) has a positive and significant link with profit efficiency of domestic banks in Ghana. This implies that foreign banks tend to transfer their international expertise, quality banking services, technological knowledge and competitive pressure to domestic banks. This result is consistent with studies by Saka et al., (2012) on the Ghanaian banking industry, Karas (2010) on the Russian banking industry and Kiyota on 29 countries in SSA.

The lagged profit efficiency has a positive and significant effect on the domestic bank efficiency in the current year. This result implies that profit efficiency tends to persist from year to year and that an increase in the previous year's efficiency could help increase the current year's profit efficiency. The positive lagged profit efficiency may constitute some accumulated knowledge and technologies that may help banks to produce higher outputs. The result is in line with study by Adjei-Frimpong et al., (2014) on the banking industry in Ghana during the period 2001 to 2010 .

Liquidity (LIQD) as measured as the ratio of loans and advances to deposits indicates bank's ability to meet customer's withdrawal needs. The result shows that liquidity ratio shows a negative and significant relationship with profit efficiency of domestic banks in Ghana suggesting that, domestic banks with high liquidity ratio tend to be profit inefficient. This may be due to non-performing loans arising from the increasing number of loan defaults. The negative relationship between liquidity and profit efficiency is in line with the study by Saka et al., (2012).

Inflation, has a negative, and significant effect on profit efficiency of domestic banks. This suggests that, high inflation levels resulting from a general increase in prices leads to domestic banks in Ghana being less profit-efficient. Thus, inflation leads to high cost of production which results in a decline in revenue for domestic banks.

The growth rate of GDP indicates a positive and significant association with profit efficiency. This implies that, growth in GDP in the economy of Ghana plays an essential role to the profit efficiency of domestic banks. This finding is consistent with studies by Maudos et al., (2002) and Grigorian and Manole (2006). 
Table 6: Regression Results - Foreign Bank entry on Efficiency of Domestic Banks

\begin{tabular}{|c|c|c|c|}
\hline Dependent variable & EEF & EEF & EEF \\
\hline & (1) REM & (2) FEM & (3) GMM \\
\hline \multicolumn{4}{|l|}{ Explanatory variables } \\
\hline $\mathrm{EFF}_{\mathrm{t}-1}$ & & & $\begin{array}{l}2.151 * * \\
(0.945)\end{array}$ \\
\hline FS & $\begin{array}{l}0.181 \\
(0.251)\end{array}$ & $\begin{array}{l}0.568^{*} \\
(0.282)\end{array}$ & $\begin{array}{l}12.70^{*} \\
(7.381)\end{array}$ \\
\hline CAP & $\begin{array}{l}-0.130 \\
(0.309)\end{array}$ & $\begin{array}{l}0.600^{* *} \\
(0.220)\end{array}$ & $\begin{array}{l}0.740 \\
(0.547)\end{array}$ \\
\hline SIZE & $\begin{array}{l}-0.0250 * \\
(0.0144)\end{array}$ & $\begin{array}{l}0.108 \\
(0.0704)\end{array}$ & $\begin{array}{l}-0.131^{* *} \\
(0.0667)\end{array}$ \\
\hline LIQD & $\begin{array}{l}0.0749 \\
(0.0486)\end{array}$ & $\begin{array}{l}0.0820 \\
(0.0636)\end{array}$ & $\begin{array}{l}-0.139 * \\
(0.0839)\end{array}$ \\
\hline EXP & $\begin{array}{l}-0.00325^{* *} \\
(0.00129)\end{array}$ & $\begin{array}{l}-0.0591 * \\
(0.0279)\end{array}$ & $\begin{array}{l}0.00440 \\
(0.00443)\end{array}$ \\
\hline HHI & $\begin{array}{l}4.769^{* * *} \\
(1.457)\end{array}$ & $\begin{array}{l}-1.954 \\
(2.799)\end{array}$ & $\begin{array}{l}9.064 \\
(6.440)\end{array}$ \\
\hline INFL & $\begin{array}{l}-0.00593 * * * \\
(0.00185)\end{array}$ & $\begin{array}{l}-0.00835^{* * *} \\
(0.00159)\end{array}$ & $\begin{array}{l}-0.00702^{* *} \\
(0.00327)\end{array}$ \\
\hline GDPG & $\begin{array}{l}-0.00879 \\
(0.00644)\end{array}$ & $\begin{array}{l}-0.00155 \\
(0.00422)\end{array}$ & $\begin{array}{l}0.0214^{*} \\
(0.0130)\end{array}$ \\
\hline Constant & $\begin{array}{l}1.345^{* * *} \\
(0.277)\end{array}$ & $\begin{array}{l}0.207 \\
(0.643)\end{array}$ & $\begin{array}{l}1.402^{* *} \\
(0.677)\end{array}$ \\
\hline Observations & 122 & 122 & 111 \\
\hline R-squared & 0.184 & 0.307 & \\
\hline Wald chi2 & 102.7 & & 1543.58 \\
\hline Prob $>$ chi 2 & 0.000 & & 0.000 \\
\hline Arellano-Bond [AR (2), Prob > Z] & & & 0.535 \\
\hline
\end{tabular}

Note: Robust Standard error in parentheses.

$*, * *$, and ${ }^{* * *}$ correspond to $10 \%, 5 \%$ and $1 \%$ significance, respectively.

\section{Concluding Remarks}

This paper has sought to investigate the effect of the influx of foreign banks in Ghana on domestic banks. More specifically, the study first compares the efficiency level of foreign banks with that of domestic banks and second, investigates the effect of foreign bank entry on the efficiency of domestic banks in Ghana. The study applies the Stochastic Frontier Analysis (SFA) technique and the system Generalized Method of Moments (GMM) estimator on bank specific level data, spanning the period 2000 to 2015 .
The results show that foreign banks with an average profit efficiency of $73.7 \%$ are more profit efficient than domestic banks with a score of $69.2 \%$ which conforms to the global advantage hypothesis. This suggests that foreign banks are able to maximize revenue through the generation of interest income on loans and investments better than domestic banks due to the foreign banks' comparative advantage in terms of international expertise. Further, the system GMM results indicate that the entry of foreign banks has contributed to the profit efficiency of domestic 
banks in Ghana. This positive spillover effect of foreign banks is manifested in their transfer of international expertise, technological knowledge, quality banking services and competitive pressure to domestic banks. In addition, previous year's profit efficiency, liquidity, inflation and gross domestic product are essential determinants of the profit efficiency of domestic banks in Ghana. The findings of the study imply that bank regulators in developing countries should push for reforms that eliminate implicit and explicit barriers that may hinder the entry of foreign or new banks.

\section{REFERENCES}

Adjei, E. A., \& Chakravarty, S. P. (2012). Banking industry liberalization in Ghana. Review of Development Finance, 2(2), 93-99.

Adjei-Frimpong, K., Gan, C., \& Hu, B. (2014). Cost efficiency of Ghana's banking industry: A panel data analysis. The International Journal of Business and Finance Research, 8(2), 69-86.

Alhassan, A. L., \& Ohene-Asare, K. (2016). Competition and bank efficiency in emerging markets: empirical evidence from Ghana. African Journal of Economic and Management Studies, 7(2), 268-288.

Aigner, D. J., \& Chu, S. F. (1968). On estimating the industry production function. The American Economic Review, 58(4), 826-839.

Arellano, M., \& Bover, O. (1995). Another look at the instrumental variable estimation of error-components models. Journal of econometrics, 68(1), 29-5

Banking Act (2004). Act 673. Accra: Ghana.

Battese, G. E., \& Corra, G. S. (1977). Estimation of a production frontier model: with application to the pastoral zone of Eastern Australia. Australian Journal of Agricultural Economics, 21(3), 169-179.

Berger, A. N., \& Humphrey, D. B. (1997). Efficiency of financial institutions: International survey and directions for future research. European Journal of Operational Research, 98(2), 175-212.

Berger, A. N., \& Mester, L. J. (1997). Inside the black box: What explains differences in the efficiencies of financial institutions? Journal of Banking \& Finance, 21(7), 895-947.
Berger, A. N., \& Mester, L. J. (2003). Explaining the dramatic changes in performance of US banks: technological change, deregulation, and dynamic changes in competition. Journal of Financial Intermediation, 12(1), 57-95.

Berger, A. N., DeYoung, R., Genay, H., \& Udell, G. F. (2000). Globalization of financial institutions: Evidence from crossborder banking performance. BrookingsWharton Papers on Financial Services, 2000(1), 23-120.

Blundell, R., \& Bond, S. (1998). Initial conditions and moment restrictions in dynamic panel data models. Journal of Econometrics, 87(1), 115-143.

Bokpin, G. A. (2013). Ownership structure, corporate governance and bank efficiency: an empirical analysis of panel data from the banking industry in Ghana. Corporate Governance: The International Journal of Business in Society, 13(3), 274-287.

Claessens, S., Demirgüç-Kunt, A., \& Huizinga, H. (2001). How does foreign entry affect domestic banking markets?. Journal of Banking \& Finance, 25(5), 891-911.

Clarke, G. R., Cull, R., \& Shirley, M. M. (2005). Bank privatization in developing countries: A summary of lessons and findings. Journal of Banking \& Finance, 29(8-9), 1905-1930.

Cohen, J. (1988). Statistical power analysis for the behavioral sciences:

Detragiache, E., Tressel, T., \& Gupta, P. (2008). Foreign banks in poor countries: theory and evidence. The Journal of Finance, 
63(5), 2123-2160.

Debreu, G. (1951). The coefficient of resource utilization. Econometrica: Journal of the Econometric Society, 273-292.

Farrell, M. J. (1957). The measurement of productive efficiency. Journal of the Royal Statistical Society. Series A (General), 120(3), 253-290.

Ghana Banking Survey. (2015). Bank of the Future: What bank customers want to experience by 2020. Accra: PWC.

Grigorian, D. A., \& Manole, V. (2006). Determinants of commercial bank performance in transition: an application of data envelopment analysis. Comparative Economic Studies, 48(3), 497-522.

Ikhide, S. I. (2000). Efficiency of commercial banks in Namibia (No. 4). Bank of Namibia, Research Dept.

Karas, A., Schoors, K., \& Weill, L. (2010). Are private banks more efficient than public banks? Economics of Transition, 18(1), 209244.

Kirkpatrick, C., Murinde, V., \& Tefula, M. (2008). The measurement and determinants of $\mathrm{x}$-inefficiency in commercial banks in Sub-Saharan Africa. The European Journal of Finance, 14(7), 625-639.

Kiyota, H. (2011). Efficiency of commercial banks in Sub-Saharan Africa: A comparative analysis of domestic and foreign banks (No. 2011, 58). Working paper//World Institute for Development Economics Research.

Koopmans, T. C. (Ed.). (1951). Activity analysis of production and allocation (No. 13). New York: Wiley.

Lensink, R., Meesters, A., \& Naaborg, I. (2008). Bank efficiency and foreign ownership: Do good institutions matter? Journal of Banking \& Finance, 32(5), 834-844.

Liuhto, K., Sorg, M., \& Uiboupin, J. (2006). Foreign banks entry and bank performance in the CEE countries. Banks and Bank Systems, 1(3), 41-59.

Maudos, J., Pastor, J. M., \& Serrano, L. (2000). Convergence in OECD countries: technical change, efficiency, and productivity. Applied Economics, 32(6), 757-765.

Meeusen, W., \& Van den Broeck, J. (1977). Efficiency estimation from Cobb-Douglas production functions with composed error. InternationalEconomic Review, 435-444.

Osei-Assibey, E., \& Asenso, J. K. (2015). Regulatory capital and its effect on credit growth, non-performing loans and bank efficiency: Evidence from Ghana. Journal of Financial Economic Policy, 7(4), 401-420.

Roodman, D. (2009). A note on the theme of too many instruments. Oxford Bulletin of Economics and Statistics, 71(1), 135-158.

Rouissi, R. B., \& Bouzgarrou, H. (2012). Cost efficiency of French commercial banks: domestic versus foreign banks. The International Journal of Business and Finance Research, 6(4), 101-112.

Saka, A. N. A., Aboagye, A. Q., \& Gemegah, A. (2012). Technical efficiency of the Ghanaian banking industry and the effects of the entry of foreign banks. Journal of African Business, 13(3), 232-243.

Sealey, C. W., \& Lindley, J. T. (1977). Inputs, outputs, and a theory of production and cost at depository financial institutions. The Journal of Finance, 32(4), 1251-1266.

Shephard, R. W. (1953). Cost and Production Functions. Princeton, NJ, Princeton University Press.

Shephard, R. W. (1970). Theory of Cost and Production Functions Princeton, Princeton University Press.

Sturm, J. E., \& Williams, B. (2004). Foreign bank entry, deregulation and bank efficiency: Lessons from the Australian experience. Journal of Banking \& Finance, 28(7), 1775-1799.

Tabak, B. M., Fazio, D. M., \& Cajueiro, D. O. (2011). Profit, cost and scale efficiency for Latin American banks: Concentration-performance relationship (No. 244).

World Bank (2016). World Development Indicators (WDI), Washington, DC: World Bank. 


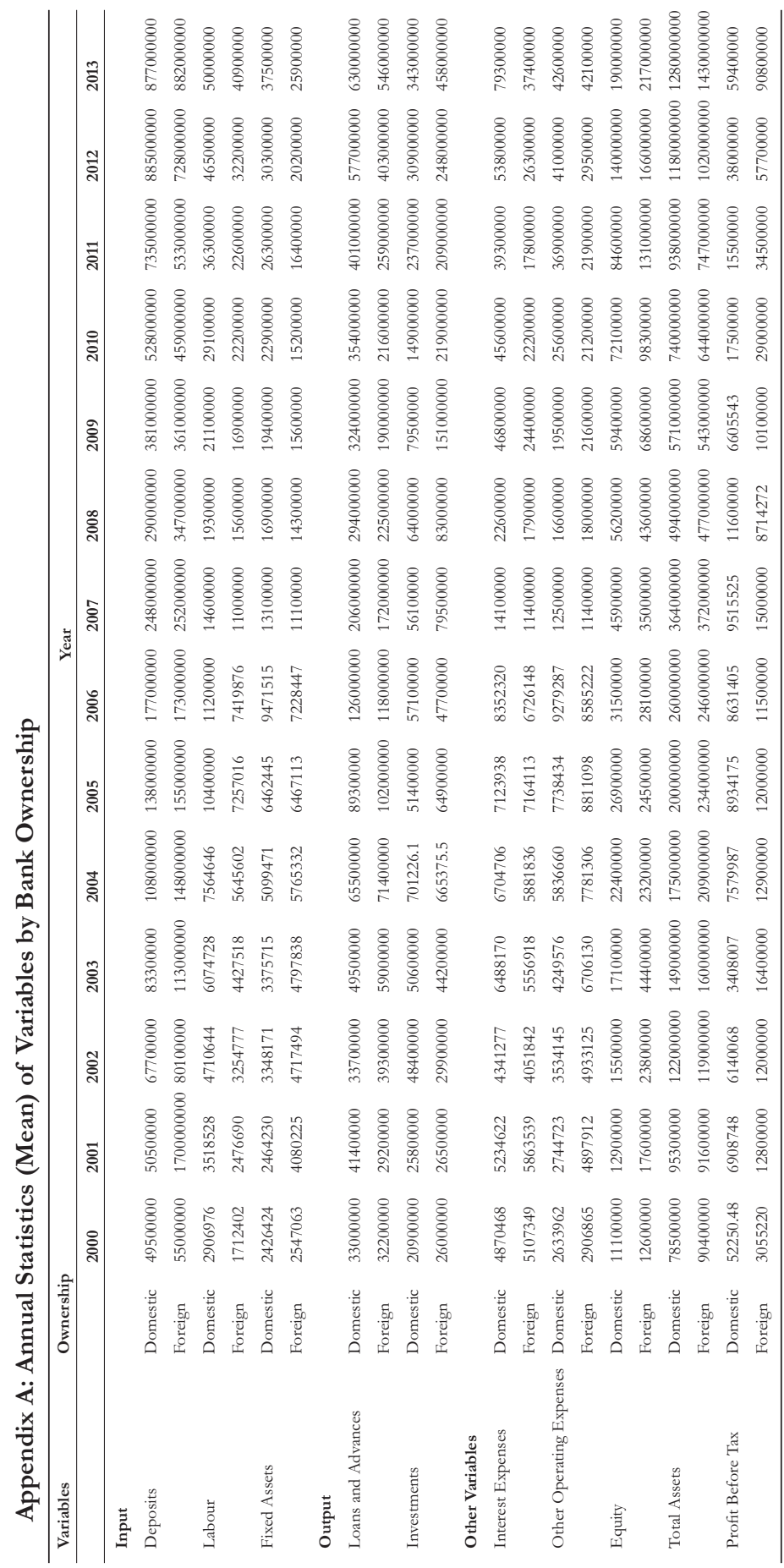

African Journal of Management Research (AJMR) 